\title{
SUSTAINABLE DEVELOPMENT AND WASTE MANAGEMENT IN EU28 COUNTRIES
}

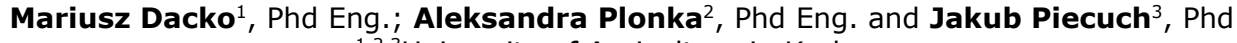

$1,2,3$ University of Agriculture in Krakow

\begin{abstract}
Sustainable development depends, among other things, on how much waste a particular society generates and how it handles it. The paper relies on Eurostat data on municipal waste management in EU28 countries. Three diagnostic variables were selected, and then taxonomic development meters (Polish: TMD) were estimated and interpreted. The research has shown that in the European Union, which is sensitive to the issues of environmental protection and sustainable development, waste management models adopted by the different member states are in many cases far from ideal. The aim of this review and empirical research was to evaluate the situation of municipal waste management. According to the authors, the positions assigned to the different countries based on TMD meter can be considered as objective measures of social responsibility for the present and future generations - which is a key aspect of sustainable development.
\end{abstract}

Key words: waste, sustainable development, taxonomy, EU28 countries.

JEL code: Q56.

\section{Introduction}

According to the hierarchy of waste management, waste should be prevented in the first place, and if that is impossible, it should be limited, and then recovered. The waste that could not have been prevented and recovered should be disposed of in accordance with the requirements of the environmental protection. It should be deposited only as a last resort. If that is the case, this activity should be legal and meet the standards in terms of selection of the location as well as construction and use of the relevant facility. In case of waste depositing, it is important what type of waste is deposited as well as its pre-processing, which is aimed at reducing the volume or potential harmfulness of waste. Of importance in the context of the environmental protection and sustainable development is also control over landfills after their closure.

Minimising the amount of waste while maintaining a high level of matter and energy recovery is currently a challenge to every modern economy. It is also of key importance to societies that take seriously the postulate of intergenerational justice, which is a key element of the definition of sustainable development.

The paper presents a review and empirical research. Its aim was to evaluate the situation of the different member states of the EU28 in terms of municipal waste management. To achieve the research objectives, Eurostat data was used to select three diagnostic variables, and then taxonomic development meters (Polish: TMR) were estimated and interpreted. The results of the taxonomy were complemented by review of up-to-date literature devoted to the issue of waste.

\section{Modern economics and problems of waste management}

Global production of municipal waste has reached an enormous scale in the present-day world. In the European Union alone, 250 billion tons of waste is generated per year, which gives $487 \mathrm{~kg}$ per capita. In a society characterised by mass production and consumption, waste is produced very

\footnotetext{
${ }^{1}$ Mariusz Dacko PhD Eng.; The University of Agriculture in Krakow, Poland

The Faculty of Agriculture and Economics, the Institute of Economic and Social Sciences, the Department of Economics and Organization of Agriculture,

e-mail: m.dacko@ur.krakow.pl

2 Aleksandra Płonka PhD Eng.; The University of Agriculture in Krakow, Poland

The Faculty of Agriculture and Economics, the Institute of Economic and Social Sciences, the Department of Economics and Organization of Agriculture,

e-mail: a.plonka@ur.krakow.pl (corresponding author)

3 Jakub Piecuch PhD; The University of Agriculture in Krakow, Poland

The Faculty of Agriculture and Economics, the Institute of Economic and Social Sciences, the Department of Economy and Economic Policy, e-mail: jakub.piecuch@urk.edu.pl
} 
easily. According to the World Counts website, as many as $99 \%$ of the things we buy become waste within half a year. The same website warns that the modern civilisation extracts such a huge amount of resources and generates so much waste that if this trend continues, we will soon need a second earth. Nevertheless, economists' views on resource-related barriers to growth are still polarised they oscillate between clear optimism and extreme pessimism (Dacko M., 2011a). According to Nazarko J. and Dobrzyski M. (2006), economics still treats natural resources as a "gift" from nature rather than a purchased good with some environmental costs involved. Czaja S. and Fiedor B. (2010) cite an interesting reflection made by Boulding, pointing out that the traditional economy corresponds to the concept of the "cowboy" economy, where the problem of limited resources is hardly taken into consideration. Meanwhile, Kwasnicki W. (2009) holds an optimistic view, arguing that human adaptability, invention and creativity will as always help to overcome the emerging problems. Surely, with the resources shrinking, the world needs them more and more urgently. In this context, searching for ways to rationally manage own waste seems to be an activity of significant importance to every economy.

Current global trends and theoretical concepts in economics do not turn a blind eye to the issue of waste. One of them is an increasingly popular approach referred to as circular economy (Korhonen J. et al., 2018; Mahpour A., 2018). Today, the circular economy is not only a theoretical economic model (Geissdoerfer M. et al., 2017). In France, it was adopted as a strategic objective, and in China it underlay the 5-year economic plan over a decade ago (Ekonomia cyrkularna..., 2018). It originated from observing natural ecosystems, where nothing is wasted and what one species does not need is essential for survival of another. An important foundation of the circular economy is systemic approach - production processes should be so designed that they take into account their environment and resemble processes observed in sustainable natural systems. Therefore, the circular economy is referred to as a study of sustainability, which clearly makes a reference to the idea of sustainable development, which has already been established in social consciousness (Dacko M., 2011a; Dacko M., 2011b; Poskrobko B., 2013; Kuder D., 2014; Dacko M., Plonka A. 2017; Dobrota D., Dobrota G., 2018).

Sustainable development underlies the European Union's policy, which is manifested in sources of universal law, i.e. in resolutions and directives. For many decades, sustainable development has also been underlying EU strategies and programmes of actions to promote the protection of the environment. The obligation to follow its principles was introduced into laws concerning the protection and management of environmental resources and into local law (Dacko M., Dacko A., 2018). Thus, by extension, the principles of sustainable development must also govern waste management. In social sciences, sustainable development is regarded as a world view, model, best practice of modern civilisation (Poskrobko B., 2013; Kuder D., 2014; Matysiak A., Strus M., 2015; Zadroga A., 2016), according to which the satisfaction of the present needs of society cannot prevent satisfaction of the needs of future generations. This idea is considered in modern economics in terms of a paradigm, which should replace the obsolete primacy of economic growth. For waste management, it means seeking solutions that will allow the economy and the environment to not exclude each other - frugal and effective use of resources, and above all the necessity of putting limits on one's own needs (Dacko M., 2011a; Dacko M., 2011b).

Waste is also a key aspect of the bioeconomy (O'Callaghan K., 2016; Patermann C., Aguilar A., 2018). This idea, like the circular economy, also refers to sustainable development, but involves sustainable use of biological renewable resources (in particular waste) to create goods and services. 
In 2012, bioeconomy was raised in the European Union to the level of a strategy and a plan of actions that have to be undertaken by 2010 to convert the existing European economy into economy based on sustainable development and new biological technologies. Bioeconomy is activity that relies on innovation and knowledge. It involves, among other things, production and processing of biomass into food, clothes, medicinal and industrial products and energy.

In the context of waste, it is also worth mentioning sharing economy (Richards T. J., Hamilton S. F., 2018). It involves increasing the effectiveness of the use of resources in distributed networks of individuals and communities, who provide services to one another, share goods, and create or produce them jointly. Frenken K. and Schor J. (2017) note that in the past people shared things as well, but the sharing was limited to close circles of known and trusted people such as the family, friends and neighbours. In the information society, sharing became possible among people who do not know one another or do not have common friends or acquaintances. It is worth stressing that it is sharing economy that underlies the zero waste movement (Zero waste..., 2018). New technologies have opened up to sharing economy a vast new field for development in the area of resources saving and use, and - naturally - waste reduction. This is an increasingly profiTable business, and at the same time an increasingly popular new philosophy of life and inspiration for new technologies (Swiat bez..., 2018).

\section{Research results and discussion}

In the light of Eurostat data (2018), deposition (although regarded as a last resort) continues to be a popular form of municipal waste management in many countries of the European Union. In 2016 , as much as $83 \%$ of waste in Malta was deposited. The situation was similar in Greece (82\%), Croatia (77\%) and Cyprus (75 \%). The infamous ranking of EU member states also includes Romania (69\%), Bulgaria (64\%), Slovakia (65\%) and Latvia (64\%). It is easy to notice that the problem of littering affects many attractive countries in terms of tourism, despite the fact that their economies depend in particular on a good condition of the natural environment.

Despite innovative solutions and practices observed in neighbouring countries, many European Union member states show an established passivity against the need to seek ways to manage their own waste and that left by tourists. For instance, in Slovenia, which is Croatia's neighbour, only $20 \%$ of municipal waste is currently deposited. In Austria, which is a neighbour of the Czech Republic, Slovakia and Hungary (which deposit almost half of their waste), only $3 \%$ of waste is deposited. Poland, which still deposits a significant share of its waste, is another country that should look closer at the solutions adopted in neighbouring countries. Germany, Denmark and Sweden are European leaders in terms of managing own waste. In these countries, only around $1 \%$ of waste is deposited today.

A more comprehensive assessment of the situation of waste management in the different countries of EU28 can be made by means of Hellwig's model taxonomy (Hellwig Z., 1968; Pietrzak M., 2014). Using Eurostat data for 2017, a set of three diagnostic characteristics was selected (kg per capita): C1 - waste generated, C2 - incineration and recovery, C3 - landfill and other (Eurostat, 2017). After standardisation (C1s, C2s, C3s), the characteristics were divided into stimulants and destimulants, and then their model values were established (for stimulants - max $\mathrm{Ci}$, for destimulants - min $\mathrm{Ci}$ ). In the next step, distance from the pattern (DIST) was calculated for each country using Euclidean metric (root of the sum of squares of the differences between a characteristic and pattern). 
On this basis, taxonomic development meter was calculated for each country (Table 1) according to the following formula: TMR=1-(DIST/ds+2sd).

Table 1

Linear ordering of waste management models in EU28 countries based on TMR

\begin{tabular}{|c|c|c|c|c|c|c|c|c|c|c|}
\hline No & $\begin{array}{c}\text { Country } \\
\text { EU28 }\end{array}$ & C1 & C1s & $\mathbf{C 2}$ & C2s & C3 & C3s & DIST & TMR & Class. \\
\hline 1. & Belgium & 409 & -0.67 & 176 & 0.52 & 4 & -1.06 & 2.55 & 0.55 & 1 \\
\hline 2. & Bulgaria & 416 & -0.60 & 15 & -0.99 & 249 & 0.65 & 4.32 & 0.24 & 3 \\
\hline 3. & Czech Republic & 344 & -1.26 & 60 & -0.56 & 167 & 0.08 & 3.57 & 0.37 & 2 \\
\hline 4. & Denmark & 781 & 2.72 & 413 & 2.75 & 7 & -1.04 & 4.64 & 0.19 & 3 \\
\hline 5. & Germany & 633 & 1.37 & 196 & 0.71 & 6 & -1.05 & 3.87 & 0.32 & 2 \\
\hline 6. & Estonia & 390 & -0.84 & 165 & 0.42 & 75 & -0.57 & 2.62 & 0.54 & 1 \\
\hline 7. & Ireland & $581 a$ & 0.90 & $170 a$ & 0.47 & $149 a$ & -0.05 & 3.77 & 0.34 & 2 \\
\hline 8. & Greece & $498 a$ & 0.14 & $3 a$ & -1.10 & $410 a$ & 1.78 & 5.22 & 0.08 & 4 \\
\hline 9. & Spain & 462 & -0.18 & 60 & -0.56 & 248 & 0.65 & 4.12 & 0.28 & 3 \\
\hline 10. & France & 513 & 0.28 & 182 & 0.58 & 111 & -0.31 & 3.18 & 0.44 & 2 \\
\hline 11. & Croatia & 416 & -0.60 & 0 & -1.13 & 301 & 1.02 & 4.60 & 0.19 & 3 \\
\hline 12. & Italy & 489 & 0.06 & 93 & -0.25 & 114 & -0.29 & 3.68 & 0.35 & 2 \\
\hline 13. & Cyprus & 637 & 1.41 & 2 & -1.11 & 482 & 2.29 & 6.11 & -0.07 & 4 \\
\hline 14. & Latvia & 438 & -0.40 & $10 a$ & -1.03 & $181 a$ & 0.18 & 4.27 & 0.25 & 3 \\
\hline 15. & Lithuania & 455 & -0.25 & 83 & -0.35 & 149 & -0.05 & 3.67 & 0.36 & 2 \\
\hline 16. & Luxembourg & 607 & 1.14 & 271 & 1.42 & 42 & -0.80 & 3.34 & 0.41 & 2 \\
\hline 17. & Hungary & 385 & -0.89 & 62 & -0.55 & 187 & 0.22 & 3.69 & 0.35 & 2 \\
\hline 18. & Malta & 604 & 1.11 & 0 & -1.13 & 520 & 2.55 & 6.12 & -0.07 & 4 \\
\hline 19. & Netherlands & 513 & 0.28 & 227 & 1.00 & 7 & -1.04 & 2.81 & 0.51 & 1 \\
\hline 20. & Austria & 570 & 0.80 & 221 & 0.95 & 12 & -1.01 & 3.26 & 0.43 & 2 \\
\hline 21. & Poland & 315 & -1.52 & 77 & -0.41 & 132 & -0.17 & 3.31 & 0.42 & 2 \\
\hline 22. & Portugal & 487 & 0.04 & $94 b$ & -0.25 & 230 & 0.52 & 3.92 & 0.31 & 3 \\
\hline 23. & Romania & 272 & -1.92 & 12 & -1.02 & 192 & 0.25 & 3.99 & 0.30 & 3 \\
\hline 24. & Slovenia & 471 & -0.10 & 54 & -0.62 & 48 & -0.76 & 3.84 & 0.33 & 3 \\
\hline 25. & Slovakia & 378 & -0.95 & 36 & -0.79 & 229 & 0.51 & 4.00 & 0.30 & 3 \\
\hline 26. & Finland & $504 a$ & 0.20 & $276 a$ & 1.46 & $16 a$ & -0.98 & 2.48 & 0.57 & 1 \\
\hline 27. & Sweden & 452 & -0.28 & 239 & 1.12 & 2 & -1.08 & 2.32 & 0.59 & 1 \\
\hline 28. & U.K. & $483 a$ & 0.01 & $167 a$ & 0.44 & $91 a$ & -0.45 & 3.07 & 0.46 & 2 \\
\hline
\end{tabular}

a data for 2016; ${ }^{b}$ data for 2014; $d_{s}$ - average; sd - standard deviation

C1 - waste generated for 2017 ( $\mathrm{kg}$ per capita) - destimulant;

- incineration and recovery for 2017 ( $k g$ per capita) - stimulant

C2 $d_{s}=120 ; s_{d}=106 ;$ pattern after standardization $=2.75$

C3 - landfill and other for 2017 ( $k g$ per capita) - destimulant;

$d_{s}=156 ; s_{d}=143 ;$ pattern after standardization $=-1.08$

DIST - distance from the pattern; $d_{s}=3.80 ; s_{d}=0.95 ; d_{s}+2 s_{d}=5.70$

TMR - taxonomic development meter; $d_{s}=0.33 ; s_{d}=0.17$

Source: author's calculations based on ... (as an example)

Development meters (Polish: TMR) do not only illustrate the differences in waste management across EU28 countries. They also make it possible to look at the complex problem of handling waste in terms of the distance from pattern - the ideal according to sustainable development. This pattern can be described as the following options: generation of possibly the least amount of waste per capita, recovery of possibly the biggest share of waste, or depositing possibly the least amount of waste on landfills. This philosophy is reflected in the ranking in the last column of Table 1 , where 
development meter classes were determined by subtracting the value of standard deviation from the mean meter, i.e.

- class 1: TMR $\geq 0.5$

- class 2: $0.5>T M R \geq 0.33$

- class 3: $0.33>T M R \geq 0.17$

- class 4: 0.17>TMR

According to the ranking, Sweden, Finland, Belgium, Estonia and Netherland perform best in terms of waste management. These countries set standards for modern waste management, pursuing the philosophy of waste minimisation and mature waste management with a high level of energy and matter recovery. It should be noted that according to Eurostat data, in 2017 as many as 9 countries of the EU28 improved their waste management to such an extent that they deposit less than $10 \%$ of waste on landfills, and other 7 countries deposit only $10 \%$ to $33 \%$ of collected waste. In the case of waste management leaders, i.e. Sweden, Denmark, Germany, Belgium and the Netherlands, deposited waste accounts for less than $1 \%$.

In the light of the presented taxonomy, the worst situation was in Malta, Cyprus and Greece. These countries generated large quantities of per capita waste and continued to prefer waste deposition. According to Eurostat data, a significant amount of waste is generated by inhabitants of highly developed countries of Western Europe. This aspect impacted the overall assessment of waste management in Denmark (781 kg per capita) and Germany (633 kg per capita), although waste deposition in these countries was radically minimised relative to other ways of handling it. These countries, although they were not assigned to class 1, can be regarded as European leaders in recycling, with over half of their municipal waste subjected to various forms of recycling. Germany in particular performs excellently in this area - according to EEA, in 2014 it achieved $64 \%$ level of recycling (including material recovery and composting of biodegradable waste). It is, however, worth noting that already in 2004 it recycled as much as $56 \%$ of its waste. Over 10 years, Germany has improved its statistics by only 8 percentage points. Thus, it seems that without breakthrough innovations recycling as a form of waste management has reached in Germany the natural performance limit. It is impossible to improve it by engaging more citizens in the process of separation. Already today, almost $100 \%$ of German households regularly separate waste. Charging a low or even No rate for waste collection contributes to this success (Segregacja smieci..., 2018).

Waste that is collected selectively is No longer a cost or nuisance. It is not economically viable to deposit waste on landfills, as it becomes a resource with economic value (Dacko et al. 2018). For instance, thanks to the implementation of advanced incineration technologies in local heat and power plants, 4 tons of Danish waste gain the energetic value of 1 ton of oil or 1.6 tons of coal (Dacko 2011a). Its continuous stream allows Denmark to treat it in national balances as a significant source of renewable energy. Looking at recycling in the context of international rankings, situations in Poland and Lithuania look encouraging. Against 35 countries examined by EEA in the 2004-2014 period, the biggest and the most prominent improvement in recycling statistics was recorded in Lithuania (from $2 \%$ in 2004 to $30 \%$ in 2014) and in Poland (from $6 \%$ in 2004 to $32 \%$ in 2014).

There is another reason for copying waste management solutions adopted in Denmark, Germany, the Netherlands, Austria, Sweden and Belgium. Selective waste collection and an increase in the level of waste recovery and recycling were accepted as priority in the entire European Union. The European Parliament passed new regulations in April 2018 concerning the so-called waste package. The regulations aim to correct the EU's waste management and adjust it to the model of circular 
economy as described, among others, by Geissdoerfer M. et al. (2017), Korhonen J. et al. (2018) and Mahpour A. (2018). In accordance with the new directives of the EU, in 2025 at least $55 \%$ of municipal waste from households and enterprises will have to be recycled. In 2030, this limit will be $60 \%$, whereas in 2035 - $65 \%$ (Chiny zamykaja..., 2018).

In this context, many countries of the UE28 already should aim to enforce waste separation through a radical change of the rates of waste collection charges (Dacko M. et al., 2018). Otherwise they will not be able to meet the requirements of the European Union's law in the next transitional period, i.e. in 2025. In Poland, this threat has been recognised. In accordance with the regulations being currently prepared, disposal of waste in the mixed form would be four times as expensive as its separation (Segregacja smieci..., 2018). At present, the difference in the charge is often only a dozen per cent, and cannot be a sufficient economic driver for environmentally friendly practices.

In many countries of the EU28, waste separation is still a matter of the citizen's free choice, but it may become obligatory. In Belgium, waste separation has been obligatory since 2010 and monetary penalty is imposed in the case of failure to meet this obligation. In conclusion, it is worth mentioning that outside of the EU waste is deposited on truly mass scale in Macedonia (100\%), Turkey ( $84 \%$ ), Serbia (79 \%) and Montenegro (70\%). It should be born in mind that these countries are officially acknowledged as candidates to the European Community.

\section{Conclusions}

1) Referring to Tofler's theory of the three waves of civilisation development (Toffler A., 2006; Toffler A., 2007) it can be stated that each civilisation struggled with the side effect of its existence in the form of waste. In agricultural societies, waste (especially in cities) mainly posed an epidemiological risk to people and domesticated animals. Mass-produced waste of the industrial civilisation affected not only the human being, but also their environment. As a result, ecological crises ceased to have a local character, but instead became a problem of regions, and then the whole world.

2) In the context of the postulates of sustainable development, it can be noted that the unsolved problems of waste generated by previous generations were transferred to the subsequent generations - which today constitute the information civilisation. Residents of the European Union can No longer afford to ignore the problem of waste, although they still have to solve not only their own issues but also the effects of previous generations' neglects.

3) The cases of European leaders: Sweden, Finland, Belgium, Estonia and the Netherlands, show that waste does not have to be a cost or nuisance. Waste represents capital, and present-day European economies cannot afford to waste the material and energy potential that exists in their waste.

\section{Bibliography}

1. Chiny zamykaja sie na smieci (China is closing on trash) Retrieved: https://www.msn.com/pl$\mathrm{pl} /$ wiadomosci/polska/chiny-zamykają-się-na-śmieci-a-bruksela-kończy-z-wysypiskami-co-zrobi-polska/arAAx66af?ocid=spartandhp Access: 9.10.2018.

2. Czaja, S., Fiedor, B. (2010). Ekonomia srodowiska i ekologiczna jako filary ekonomii zrownowazonego rozwoju, (Environmental and ecological economics as the pillars of the economics of sustainable development). In „Ekonomia zrownowazonego rozwoju” (,Economics of sustainable development”). Wydawnictwo Wyzszej Szkoły Ekonomicznej w Bialymstoku, pp. 30-52.

3. Dacko, M. (2011a). Model rozwoju obszarow wiejskich objetych siecia Natura 2000 (Model of development of rural areas covered by the Natura 2000 network). In „Uwarunkowania zrownowazonego rozwoju gmin objetych siecia Natura 2000 w swietle badan empirycznych" ("Conditions for the sustainable development of communes included in the Natura 2000 network in the light of empirical research"). Wydawnictwo Instytutu Rozwoju Wsi i Rolnictwa PAN, Warszawa, pp. 325-360. 
4. Dacko, M. (2011b). Koncepcja zrownowazonego rozwoju w naukach ekonomicznych -inspiracje, ewolucja, perspektywy (The concept of sustainable development in economic sciences - inspirations, evolution, perspectives). In „Natura 2000 jako czynnik zrownowazonego rozwoju obszaow wiejskich regionu Zielonych Pluc Polski" (Natura 2000 as a factor in the sustainable development of rural areas of the Green Lungs of Poland"). Wydawnictwo Instytutu Rozwoju Wsi i Rolnictwa PAN, Warszawa, pp. 19-42.

5. Dacko, M., Dacko, A., Mazur, G. (2018). Gospodarka odpadami a zrownowazony rozwoj lokalny (Waste management versus sustainable local development). Roczniki Naukowe Stowrzyszenia Ekonomistow Rolnictwa i Agrobiznesu XX (3), pp. 34-40.

6. Dacko, M., Plonka, A. (2017). Idea rozwoju zrownowazonego w opiniach i postawach rolnikow (Idea of sustainable development in the opinions and attitudes of farmers). Roczniki Naukowe Stowrzyszenia Ekonomistow Rolnictwa i Agrobiznesu XIX (1), pp. 38-43.

7. Dobrotă, D., Dobrotă, G. (2018). An Innovative Method in the Regeneration of Waste Rubber and the Sustainable Development, Journal of Cleaner Production, Volume 172, pp. 3591-3599.

8. Ekonomia cyrkularna - utopia czy koniecznosc (Circular economy - utopia or necessity) Retrieved: http://zielonewiadomosci.pl/tematy/ekologia/ekonomia-cyrkularna-utopia-czy-koniecznosc/ Access: 09.10 .2018$.

9. Eurostat. (2017). Retrieved: http://appsso.eurostat.ec.europa.eu/nui/show.do?dataset=env_wasmun\&lang=en Access: 21.01.2019.

10. Frenken, K., Schor, J. (2017). Putting the Sharing Economy Into Perspective, Environmental Innovation and Societal Transitions, Volume 23, pp. 3-10.

11. Geissdoerfer M., Savaget P., Bocken N., Hultink E. (2017). The Circular Economy - A New Sustainability Paradigm? Journal of Cleaner Production, Volume 143, pp. 757-768.

12. Hellwig, Z. (1968). Zastosowanie metody taksonomicznej do typologicznego podzialu krajow ze wzgledu na poziom ich rozwoju oraz zasoby i strukture wykwalifikowanych kadr (Application of the taxonomic method to the typological division of countries due to the level of their development and the resources and structure of qualified personnel). Przegad Statystyczny 15 (4), pp. 307-327.

13. Korhonen, J., Honkasalob, A., Seppäläc, J. (2018). Circular Economy: The Concept and its Limitations. Ecological Economics, Volume 143, pp. 37-46.

14. Kuder, D. (2014). Nowe modele wzrostu gospodarczego a paradygmat zrownowazonego rozwoju (New Models of Economic Growth and Paradigm of Sustainable Development). Nierownosci Spoleczne a Wzrost Gospodarczy, Volume 38, pp. 27-39.

15. Kwasnicki, W. (2009). Amalteisci i neomaltuzjanie - dwie wizje rozwoju (Amalteists and neo-Imperialism two visions of development). Ekonomista 3/2009, pp. 1-26.

16. Mahpour, A. (2018). Prioritizing Barriers to Adopt Circular Economy in Construction and Demolition Waste Management. Resources, Conservation and Recycling, Volume 134, pp. 216-227.

17. Matysiak, A., Strus, M. (2015). Paradygmat rozwoju zrownowazonego (Sustainable development paradigm). Studia Ekonomiczne Zeszyty Naukowe Uniwersytetu Ekonomicznego, Volume 213, pp. 11-21.

18. Nazarko, J., Dobrzynski, M. (2006). Zrownowazony rozwoj-podejscie holistyczne (Sustainable development - a holistic approach). In „Uwarunkowania ochrony srodowiska” (Conditions for environmental protection”). Wydawnictwo Difin, Warszawa, p. 8-22.

19. O'Callaghan, K. (2016). Technologies for the Utilisation of Biogenic Waste in the Bioeconomy. Food Chemistry, Volume 198, pp. 2-11.

20. Patermann, C., Aguilar A. (2018). The Origins of the Bioeconomy in the European Union. New Biotechnology, Volume 40, part A, pp. 20-24.

21. Pietrzak, M. B. (2014). Taksonomiczny miernik rozwoju (TMR) z uwzględnieniem zaleznosci przestrzennych (Taxonomic measure of development (TMD) with the inclusion of spatial dependence). Przeglad Statystyczny, Volume LXI, Issue 2, pp. 181-201.

22. Poskrobko, B. (2013). Paradygmat zrownowazonego rozwoju jako wiodacy kanon w badaniu nowych obszarow ekonomii (The Paradigm of Sustainable Development as the Leading Standard in the Research on New Spheres of Economics), Ekonomia i Srodowisko, 3(46), pp. 10-24.

23. Richards, T. J., Hamilton, S. F. (2018). Food Waste in the Sharing Economy. Food Policy, Volume 75, pp. 109-123.

24.Segregacja smieci - jak sobie z nia radza Europejczycy (Segregation of rubbish - how Europeans deal with it) Retrieved: https://muratordom.pl/prawo/porady-prawne/segregacja-smieci-jak-sobie-z-nia-radzaeuropejczycy-zobacz-jak-sortuja-odpady-wlosi-belgowie-niemcy-aa-GWzv-MFHo-GN2c.html Access: 20.04.2018.

25. Swiat bez smieci (A world without rubbish). Retrieved: http://weekend.gazeta.pl/weekend/1,152121,18284522,Swiat_bez_smieci_Poznajcie_filozofie_zerowaste_i .html Access: 23.03.2018.

26.Toffler, A. (2006). Trzecia fala (The third wave), Wydawnictwo Kurpisz S.A., Poznan.

27.Toffler, A. (2007). Szok przyszlosci (Future shock), Wydawnictwo Kurpisz S.A., Poznan.

28. Zadroga, A. (2016). Sustainable development jako paradygmat rozwoju spoleczno-gospodarczego (Sustainable development as a paradigm of socio-economic development). In „Przestrzenie badawcze mlodych naukowcow. Inspiracje-Innowacje-Wdrożenia” (,Research spaces of young scientists. InspirationInnovation-Implementation"). Wydawnictwo Katolickiego Uniwersytetu Lubelskiego, Lublin, pp.11-24.

Zero Waste Home Retrieved: https://zerowastehome.com/about/bea/ Access: 23.03.2018. 